\begin{abstract}
Бычкова Гульфира Мубараковна, к.э.н., доцент, Ангарский государственный технический университет, e-mail: gulfira_agta@mail.ru

\section{УПРАВЛЕНИЕ ДЕЛОВЫМ РИСКОМ: ПРИКЛАДНОЙ АСПЕКТ}

Bychkova G.M.

\title{
BUSINESS RISK MANAGEMENT: AN APPLIED ASPECT
}

\begin{abstract}
Аннотация. Разработаны рекомендации по дополнению информационной базы портала «Зачестный бизнес», обеспечивающие возможность разработки и внедрения модели оценки делового риска бизнеса.

Ключевые слова: информационная база, деловой риск, оценка, финансовая модель.

Abstract. Recommendations have been developed to supplement the information base of the portal "Honest Business", providing the opportunity to develop and implement a business risk assessment model.
\end{abstract}

Keywords: information base, business risk, valuation, financial model.

Проблема, на решение которой направлено данное исследование, это необходимость повышения коэффицциента полезного использования мощной информационной базы, формируемой в учетной среде бизнеса. Актуальность определяется заинтересованностью внешних пользователей (инвесторов, кредиторов, поставщиков, покупателей) в получении ключевых аналитических показателей из указанной информационной базы для принятия управленческих решений.

Одной из таких баз является портал «За честный бизнес». Цель исследования - анализ качества информационной базы портала с точки зрения возможности оценки одного из ключевых показателей - делового риска бизнеса. Задачи исследования: выявить резервы совершенствования качества информационной базы сайта; разработать модели оценки делового риска бизнеса, апробировать модели на материалах сайта.

Объект исследования - портал «За честный бизнес», предмет исследования - процесс формирования информации, необходимой для оценки делового риска. К настоящему времени основные составляющие сайта определены: бухгалтерский баланс, отчет о фринансовых результатах (ОФР), отчет о движении денежных средств, краткая характеристика бизнеса. Представлены основные показатели: коэффрициенты ликвидности, автономии, капитализации, обеспеченности собственными оборотными средствами, рентабельности активов, собственного капитала, рентабельности продаж. При этом, в большинстве ОФР не содержится информация о величине коммерческих и управленческих расходов, которые с определенной долей условности носят постоянный характер. Именно на их основе можно дополнить аналитические показатели - выполнить экспресс анализ делового риска бизнеса (расчет точки безубыточности и запаса фринансовой прочности) [1]. Это и является, по нашему мнению, основным резервом улучшения качества информационной базы портала. Для использования этого резерва можно обратиться с предложением к налоговым органам в 
оказании содействия - при приеме отчетности акцентировать внимание налогоплательщика на необходимость заполнения строк 2210 и 2220 ОФР. Для апробации используем размещенные на портале данные ОФР АО "Тихвин", таблица 1.

Таблица 1 - Отчет о финансовых результатах АО "Тихвин", руб.

\begin{tabular}{|c|l|c|c|c|}
\hline № & \multicolumn{1}{|c|}{ Показатель } & 2018 & 2017 & 2016 \\
\hline 1 & Выручка & 92496000 & 78316000 & 21182000 \\
\hline 2 & Себестоимость продаж & 62536000 & 55306000 & 17064000 \\
\hline 3 & Валовая прибыль (убыток) & 29960000 & 23010000 & 4118000 \\
\hline 4 & Коммерческие расходы & 21003000 & 10491000 & 130000 \\
\hline 5 & Управленческие расходы & 5445000 & 10479000 & 3041000 \\
\hline 6 & Прибыль (убыток) от продаж & 3512000 & 2040000 & 947000 \\
\hline
\end{tabular}

Представим предлагаемую для практических расчетов фринансовую модель расчета показателей делового риска в формате электронных таблиц, в пПП Excel, таблица 2.

Таблица 2 - Расчет показателей делового риска

\begin{tabular}{|c|l|c|c|c|}
\hline \multirow{2}{*}{ № } & \multicolumn{1}{|c|}{ Показатель } & \multicolumn{3}{|c|}{ Оценка } \\
\cline { 2 - 4 } & \multicolumn{1}{|c|}{2018} & 2017 & 2016 \\
\hline 1 & $\begin{array}{l}\text { Маржинальный доход (выручка - себестоимость про- } \\
\text { даж), руб. }\end{array}$ & 29960000 & 23010000 & 4118000 \\
\hline 2 & $\begin{array}{l}\text { Постоянные расходы (управленческие + коммерче- } \\
\text { ские), руб. }\end{array}$ & 26448000 & 20970000 & 3171000 \\
\hline 3 & $\begin{array}{l}\text { Удельный вес маржинального дохода в выручке, в до- } \\
\text { лях единицы }\end{array}$ & 0,32 & 0,29 & 0,19 \\
\hline 4 & $\begin{array}{l}\text { Стоимостная оценка точки безубыточности, руб. (стр. 2 } \\
\text { :стр. 3) }\end{array}$ & 81653345 & 71372730 & 16310860 \\
\hline 5 & $\begin{array}{l}\text { Запас финансовой прочности, руб. (стр. 1, табл.1 -стр. } \\
\text { 4) }\end{array}$ & 10842655 & 6943270 & 4871140 \\
\hline 6 & $\begin{array}{l}\text { Запас финансовой прочности, \% (стр. 5 : выручка х } \\
\text { 100\%) }\end{array}$ & 11,72 & 8,87 & 23 \\
\hline
\end{tabular}

В нашем случае увеличение хозяйственного оборота - выручки от продаж, сопровождается повышением показателя делового риска, снижением запаса фринансовой прочности. Предлагаемая модель универсальна, может быть использована хозяйствующими субъектами различных организационноправовых форм, масштабов и видов деятельности. Область применения в рамках своего бизнеса - для контроля и анализа динамики показателей. Кроме того, используя информацию портала по основному виду деятельности бизнеса (ОКВЭД) можно отслеживать динамику этого показателя у ближайших конкурентов. Дополнение портала показателем оценки делового риска будет способствовать расширению его аналитических возможностей и обеспечит возможность использования предлагаемой модели для управления бизнесом.

\section{ЛИТЕРАТУРА}

1. Григорьева Т.И. Финансовый анализ для менеджеров: оценка, прогноз / Т.И. Григорьева. - М.: Юрайт, 2017. 